\title{
1 Seasonal migration as a life history trait facilitating adaptation to climate change
}

2 Authors: Katherine Carbeck ${ }^{1 *}$, Tongli Wang ${ }^{1}$, Jane Reid ${ }^{2,3}$, and Peter Arcese ${ }^{1}$

$4{ }^{1}$ Department of Forest and Conservation Sciences, University of British Columbia, Vancouver, BC,

$5 \quad$ V6T1Z4, Canada

$6 \quad{ }^{2}$ School of Biological Sciences, University of Aberdeen, Aberdeen AB24 2TZ, Scotland

$7 \quad{ }^{3}$ Centre for Biodiversity Dynamics, Institutt for Biologi, NTNU, Trondheim, Norway

9 *Corresponding Author: Katherine Carbeck, katherinecarbeck@gmail.com

Data accessibility: Occurrence and climate data are publicly available from the eBird (www.ebird.org) and ClimateNA databases (www.climatena.ca).

Authors' contributions: K.C. and P.A. designed the study. K.C. and T.W. contributed to scripts. K.C. analysed the data and wrote the manuscript. K.C., T.W., J.R. and P.A. edited and improved the manuscript.

17 Competing interests: The authors declare we have no competing interests.

Acknowledgements: We are deeply grateful to the Tswaout and Tseycum First Nations Bands for allowing us to work on Mandarte Island and to the Natural Sciences and Engineering Research Council of

Canada, University of British Columbia, FRBC Chair in Conservation, Hesse Graduate fellowship, and Norwegian Research Council and NTNU Centre for Biodiversity Dynamics (SFF-III 223257) for recent and long-term support. 


\section{Abstract}

Predicting the geographic range of species and their response to variation in climate are entwined goals in conservation and evolutionary ecology. Species distribution models (SDMs) are foundational in this effort and used to visualize the geographic range of species as the spatial representation of its realized niche, or when based only on climate, its climate niche. SDMs can also forecast shifts in species range given climate change, but often lack of empirical support for causal links between climate and demography, yielding uncertain predictions. We addressed such uncertainties whilst also exploring the role of migration and resident life-histories in climate adaptation in mobile animals using 48 years of

detailed demographic and climate data for song sparrows (Melospiza melodia), a polytypic species that varies in migratory life history. We developed SDMs representing demographic and climate niches of migratory and resident populations in western North America from California (CA) to Alaska (AK) using data from a focal population in British Columbia (BC) and 1.2 million citizen science observations.

Distributions of resident and migrant populations predicted by each model agreed strongly $(72.8 \%)$ in the region of our focal population, but less well in regions with dissimilar climates. Mismatches were largest in $\mathrm{CA}$, smaller in $\mathrm{AK}$, but in all cases supported the hypothesis that climate influences the evolution of migration and limits year-round residency. Our results imply that migrants predominated in our focal population a century ago, but that climate change has favored range expansions by non-migratory phenotypes and facilitated an upward shift in the elevational range of residents. We suggest long-term studies are crucial to evaluating the predictions of SDMs positing causal links between climatic to elucidating the potential for migration or residence to facilitate adaptation to climate change.

Keywords: migratory behavior, climate adaptation, species distribution model, climate niche, 


\section{Introduction}

52 Theory and empirical evidence indicate that spatial and temporal heterogeneity in the environment can

drive variation in species distribution and life history by causing variation in individual fitness and

thereby driving natural selection and adaptation to local conditions (Wright, 1982; Wade \& Kalisz, 1990;

Schluter, 2000; Aitken et al., 2008; Hendry et al., 2018). However, the rapid pace of anthropogenic

change has raised new questions about the capacity of local populations to accommodate change (e.g.,

Gaston 2003; Mason et al., 2019; reviewed by Root et al., 2003; Parmesan, 2006; Bell, 2017) and

elevated the importance of empirical studies which allow us to estimate the pace of climate adaptation

and identify the processes underlying it (e.g., Grant \& Grant, 2006; Stoks et al., 2014; Bay et al., 2018;

Bontrager \& Angert, 2019; Radchuk et al., 2019). Theory suggests that species can avoid the negative

effects of climate change on demographic performance at a site by (1) adapting via genetic mechanisms

that increase individual fitness and facilitate persistence at sites occupied historically (Aitken et al., 2008;

Bay et al., 2018); (2) adapting to current conditions via phenotypic plasticity (i.e. phenotypic change

within existing genotypes, Ghalambor et al., 2007; Charmantier et al., 2008; Nicotra et al., 2010); and/or

(3) dispersing to new areas that now match historical climatic conditions (Angert et al. 2011; Chen et al.

2011; Gillings et al. 2015; cf Greenwood \& Harvey 1982). However, many species also harbor capacities

to respond to deteriorating environments by altering spatial patterns of seasonal migration (i.e., the

reversible movement between breeding and non-breeding areas) versus year-round residency; changes

which may arise via adaptive migratory plasticity and/or evolution (Reid et al. 2018). Here, we develop

and test the hypothesis that migration represents an additional mechanism by which mobile species can

adapt to climate change by facilitating their access to spatially and temporally limiting resources whilst

avoiding conditions that would preclude their survival at one location throughout the annual cycle.

Populations comprising a mix of seasonal migrants and year-round residents occur in diverse taxa

(e.g., fish, Chapman et al., 2012; birds, Dingle, 2014; mammals, Avgar et al., 2014; and reptiles and 
and/or plasticity in migration to enable rapid responses to environmental change (Liedvogel et al., 2011).

77 Such responses can be driven by spatial and temporal variation in the costs and benefits of seasonal migration, which may in turn give rise to correlations between environmental conditions, occurrence of migration, and life history evolution. For example, climate warming and supplemental feeding have each facilitated the establishment of resident populations in species of birds known previously as obligate migrants (Zuckerberg et al., 2011; Møller et al., 2014; Shephard et al., 2015; Plummer et al., 2015). Such transitions can elevate population growth rate in newly-established resident as compared to migrant subpopulations by enhancing over-winter survival and annual reproductive rate (Visty et al., 2018), and similar trade-offs involving individual fitness and climate can drive variation in migratory phenotype across populations. For example, Acker et al. (2021a; 2021b) reported context-dependent fitness of residents and migrants in European shags (Phalacrocorax aristotelis), wherein selection favored migrants in severe winters but residents in milder years.

In the context of climate change, such observations suggest that we should also observe temporal shifts away from the expression of seasonal migration and in favor of year-round residence in populations where climate change has ameliorated previous limits on population growth. Similarly, shifts from residence to migration might be expected in areas occupied historically by residents, but which have become inhospitable due to the negative effects of climate change on habitat, food supply, or interacting species. However, documenting such changes requires detailed knowledge of temporal and spatial variation in the occurrence of migration in populations and the demography and growth rate of such populations at large geographic ranges; two requirements rarely met in free-living species. Alternatively, one can infer continent-wide variation in the growth rates of resident versus migrant populations by extrapolating from long-term climate and demographic data collected at smaller scales. However, because datasets spanning multiple decades and completely enumerated populations are rare, it remains to be demonstrated that temporal variation in climatic factors shown to limit population growth at local scales 
101 across its historical, contemporary and/or future range. Using such relationships can predict species

102 distribution and evaluating the reliability of those predictions at regional and larger scales thus remain

103 key steps to elucidating mechanisms by which mobile species may respond change in the environment.

104 Most efforts to predict the response of species to environmental change employ species

105 distribution models (SDMs) to summarise statistical links between the occurrence of species and

106 environmental characteristics at a site (reviewed by Elith \& Leathwick, 2009). Climate niche models are a

107 particular case of SDMs that aim to predict species' distribution based solely on climatic factors known or

108 assumed to limit population growth (Andrewartha \& Birch, 1954; Wiens et al., 2009). However, such

109 models have been criticized for their opaque assumptions and inability to reveal the biological

110 mechanisms driving variation in demographic performance and species distribution (Elith \& Leathwick,

111 2009; Zurell, 2017). For example, although climate niche models make implicit predictions about

112 population growth in versus outside the climate niche, few studies test such assumptions directly (e.g.,

113 Tredennick et al., 2017; Bayly \& Angert, 2019; Williams et al., 2021). Moreover, eco-evolutionary

114 studies increasingly indicate that local adaptation to environment is common in nature (e.g., Hoban et al.

115 2016; Delph 2018), implying that some species can be expected to show heterogeneous responses to

116 climatic factors at micro-geographic to regional scales (e.g., Walsh et al., 2019; Mikles et al., 2020).

117 Because many climate niche models assume that the biological and statistical relationships between

118 climate and demography act similarly over the species range, testing their underlying mechanisms and

119 predictions will be essential to evaluating their reliability, evaluating the adaptive capacity of species, and

120 predicting how resident and migrant populations may respond to spatial and temporal heterogeneity in

121 climatic conditions.

We addressed the knowledge gaps above using 48 years of demographic data, 1.2 million citizen

123 science observations, and climate data spanning two centuries to predict the influence of historical,

124 contemporary, and future climate on population growth, and migration versus residence, in song sparrow

125 populations throughout western North America (comprising Alaska, British Columbia, Washington, 
126 Oregon, and California). To do so, we first tested several a priori hypotheses (Table 1) on the effects of

127 temporal variation in climate on survival and reproduction in a focal study population which resides year-

128 round in coastal British Columbia, Canada.

Second, we then used 'space-for-time substitution' (e.g., Pickett 1989; La Sorte et al. 2009) to

130 predict how variation in climate may affect the population growth rate $(\lambda)$, migratory status, and

131 distribution of song sparrow populations (i.e., the 'demographic niche') at larger spatial scales, assuming

132 that song sparrows in our study population and western North America respond similarly to climate. This

133 study area encompasses Mediterranean to Arctic ecosystems, an elevational range of 0 to $3200 \mathrm{~m}$, and 17

134 of 25 extant subspecies (Miller, 1956; Patten \& Pruett, 2009), including five of ‘special concern' (Pruett

135 et al., 2008; Shuford et al., 2008). Because climate is thought to play a key role in local adaptation and the

136 evolution of migration or residence in song sparrows (e.g., Aldrich 1984, Arcese et al. 2002, Mikles et al.

137 2020), they are an excellent species in which to develop and test SDMs.

138 Third, we evaluated the performance of our demographic niche model by comparing it to a

139 climate niche model generated from 1.2 million citizen science observations and contemporary climate

140 data to predict the distributions of migratory and resident populations throughout western North America.

141 Given the large scale of our study area and substantial variation in climate recorded therein, we expected

142 that mismatches between our demographic and climate niche models would increase as climatic

143 conditions diverged from those experienced in our focal study population and reveal practical limits to

144 prediction.

145 Last, we predicted how climate might influence migratory phenotype by using our demographic

146 niche model to predict the historical and future ranges of migratory and resident song sparrow

147 populations in three periods over two centuries: 1901-1910, when winter temperatures in our focal study

148 population averaged $0.9^{\circ} \mathrm{C}$ cooler than present-day (2010-2018), and 2070-2100, when winter

149 temperatures are predicted to exceed conditions 200 years earlier by $3.1^{\circ} \mathrm{C}$. We validated retrospective

150 projections using historical records before speculating on the potential role of migration versus residence 
151 in climate adaptation. By doing so, we provide a particularly detailed case study of how population

152 demography, species occurrence, and climate data can be used to explore, predict, and test for the

153 interactive effects of environmental change on the distribution, demography, and migratory dynamics of

154 mobile species.

155

156 Methods

157 Study Species

158 Twenty-four subspecies of song sparrows breed from Newfoundland to the Aleutian Islands, and south to

159 central Mexico, with 17 subspecies occurring with our study area from Alaska (AK) to California (CA).

160 Variation in size and plumage over the song sparrow range exemplify Bergmann's and Gloger's rules,

161 with the largest individuals residing year-round in near-shore habitats of the Aleutian Islands and the

162 smallest in California salt marshes, and the darkest inhabiting southeast Alaska and lightest the arid

163 southwest of North America (Aldrich, 1984; Zink \& Remsen, 1986; Patten and Pruett, 2009; Pruett \&

164 Winker, 2010). Because song sparrows are among the world's most polytypic species, display marked

165 local adaptation, and additive genetic variation in traits linked to environmental conditions (e.g., Walsh et

166 al., 2019; Mikles et al., 2020), they are an excellent species to test for spatial and temporal heterogeneity

167 in relationships between climate, population growth, and migration.

169 Focal population

170 All data on the demography of song sparrows was collected on Mandarte Is., BC, Canada (48. $8^{\circ} \mathrm{N}$,

$171 \quad 123.8^{\circ} \mathrm{W} ;$ c. 6 ha in area), where all song sparrows were identified individually and monitored from 1960-

1721962 and 1975-2018 using nearly identical methods (Tompa, 1963; Smith et al., 2006). Briefly, territories

173 were monitored each 2-5 days from mid-March to July in all years to record the behavior, survival, and

174 reproductive success of all birds. Nestlings were uniquely color-banded after hatching, observed to

175 independence from parental care ( 24-32 days of age), and recorded as having recruited to or disappeared 
176 from the population in late April the following year. High annual re-sighting probabilities $(>99 \%$;

177 Wilson et al., 2007), the enumeration of immigrants by color-banding $(<0.5$ female/yr on average; Reid

$178 \&$ Arcese 2020), continuous monitoring of breeding activity, and genetic confirmation of a 50:50 sex

179 ratio at hatching (Postma et al., 2011) facilitated high precision in our estimates of survival, reproduction,

180 and population growth. For simplicity, we only considered females when estimating demographic rates

181 and population growth here (Arcese et al., 1992; Arcese \& Marr, 2006). Smith et al. (2006), Sardell et al.

182 (2012). Lameris et al. (2016) describe the current and historical change in vegetation on the island.

184 Climate data

185 All climate data were obtained via ClimateNA (version 6.00; Wang et al. 2016), which generates scale-

186 free point data for specific locations through dynamic local downscaling of gridded historical and future

187 climate variables for individual years and periods between 1901 and 2100. Historical and contemporary

188 periods were selected based on the most recently available decadal data from ClimateNA. For building

189 climate niche and demographic models, climate data were generated for specific sample locations for the 190 contemporary period (2010-2018). For spatial predictions, monthly climate data obtained by querying

191 ClimateNA using an input file of the latitude, longitude and elevation each of 35,118,256 rasterized cells

192 in our study area (1 km² DEM; Amatulli et al., 2018). Historical (1901-1910) and future climate (2070-

193 2100) was estimated similarly. To account for uncertainty in future climate, we selected an ensemble of

19415 General Circulation Models (GCM; Coupled Model Intercomparison Project) included in the IPCC

195 Fifth Assessment Report (IPCC, 2014), and an intermediate greenhouse gas emission scenario (RCP 4.5)

196 which assumes emissions start declining around 2040 (IPCC, 2014).

\section{Demographic niche models}

199 We characterized the effects of monthly weather on demographic performance using variables shown 200 previously to predict adult survival $\left(\mathrm{S}_{\mathrm{a}}\right)$, juvenile survival $\left(\mathrm{S}_{\mathrm{j}}\right)$, reproductive success $(\mathrm{RS})$, and population 
201 growth rate $(\lambda)$ (Table 1,S1), and thought to reflect extreme winter and/or summer conditions influencing 202 energy and water balance, respectively (e.g., Arcese et al., 1992; Wilson \& Arcese, 2003; Tarwater \& 203 Arcese, 2018). $\mathrm{S}_{\mathrm{a}}$ was estimated annually as the fraction of females alive in late April each year that 204 survived to the next April. $\mathrm{S}_{\mathrm{j}}$ was estimated as the fraction of female yearlings that became independent 205 from parental care and survived on Mandarte to late April the next year. RS equaled the mean number of 206 female young that became independent of parental care per adult female in each year (see Fig. S1 for 207 timeline). Population growth rate was then calculated as $\lambda=\left(\mathrm{S}_{\mathrm{j}} * \mathrm{RS}\right)+\mathrm{S}_{\mathrm{a}}$ following Arcese \& Marr 208 (2006; see also Visty et al., 2018), assuming no further age structure or immigration.

We employed normal regression to quantify relationships between $S_{j}, S_{a}$, RS and climate. All

models initially included linear and second-order polynomial terms of each a priori predictor identified in

211 Table 1. We then reduced models using supervised backward selection to eliminate variables sequentially

212 with the least influence on model fit, such that final models only included predictors with influence $(\mathrm{p}<$

$2130.1)$ that were not closely correlated $(\mathrm{r}<0.7)$. All response variables were mean-centered and natural log-

214 transformed to facilitate climate mapping and because doing so led us to models that explained more

215 variance and exhibited better diagnostics than other approaches (Table S3). Values of $\mathrm{S}_{\mathrm{j}}$ and $\mathrm{S}_{\mathrm{a}}$ predicted

216 from generalized linear models assuming binomial errors and a logit link were well correlated to values

217 derived above ( $r=0.99$ and 0.770 , respectively); we employed the former here because similar methods

218 generated our a priori predictions (Table 1).

219 We then used our fitted demographic models to predict contemporary $\lambda$ across our study area

220 given climate (Table S3; see 'Climate data'). To do so, predicted values of $\mathrm{S}_{\mathrm{a}}$, $\mathrm{S}_{\mathrm{j}}$, and RS values were

221 back-transformed, centered on their observed means in our focal population, and bounded between 0 and

2220.99 for $\mathrm{S}_{\mathrm{a}}, 0$ and 0.69 for $\mathrm{S}_{\mathrm{j}}$, and 0 and 4.34 for $\mathrm{RS}$, which represent ranges spanning \pm 3 SEs. We used

223 the same procedure to predict historical and future $\lambda$ in relation to climate. Each map cell was classified

224 as supporting a 'resident' population if the predicted value of $\lambda$ predicted given local climate at the site

225 was $\geq 1$ (i.e., resident demographic niche), or a 'migrant' population if $\lambda<1$ (i.e., migrant demographic 
226 niche), given our assumption that the long-term persistence such populations at a site can only be 227 achieved via seasonal migration.

\section{Climate niche models}

230 To characterize relationships between migrant or residence and climate using our 'climate niche model,'

231 we first obtained all observations of song sparrows from the eBird Basic Dataset (version Sep 2019;

232 www.ebird.org/science/download-ebird-data-products) to extract presence and absence data from

233 individual checklists. eBird is a large semi-structured citizen science depository of high-quality

234 observations of birds year-round. We filtered 49,972,482 checklists for our study area (comprising

235 Alaska, British Columbia, Washington, Oregon, and California) to include only those recorded from

236 January 1, 2010 to September 1, 2019, representing 'complete checklists', with a maximum distance

237 travelled of $5 \mathrm{~km}$, and $\leq 5 \mathrm{hrs}$ of effort, and complete documentation; yielding 5,137,845 informative

238 checklists (using Auk package in R; Strimas-Mackey et al., 2018). Because eBird checklists are not

239 randomly distributed in space or time and often suffer 'class imbalance' due to more absences than

240 presences recorded, we generated a $1 \mathrm{~km}$ hexagonal grid over the study area and randomly subsampled

241 the filtered dataset to reduce bias, following Johnston et al. (2019). Subsampling had little influence on

242 prevalence but reduced checklists to $3,424,036$ (detection rate before subsampling $=33.3 \%$; after $=$

$24333.9 \%$ ). Checklists were further sorted to create 'winter' and 'breeding' distributions based on the date in

244 which observations were made, such that observations in January-February were assumed to reflect the

245 distribution of overwintering populations $(\mathrm{N}=543,837)$ and those in May-June the distribution of the

246 breeding populations $(\mathrm{N}=693,751)$, respectively $\left(\mathrm{N}_{\text {total }}=1,237,588\right)$. Ten annual climate variables

247 related to temperature and precipitation were generated for each of the sample locations. Those climate

248 variables were expected to influence the occurrence of migration and residence in song sparrows (Table

249 S2; 2010-18). 
contemporary, historical, and future ranges of migratory and resident song sparrow populations in

western North America. The species occurrence (presence or absence) was used as the dependent

variable, and the 10 climate variables were used as predictors. Random Forest works by producing a

'forest' of decision trees and aggregating the results over all trees. The decision trees are constructed with

a bootstrap sample of the input data such that the resulting 'bagged' dataset contains about $64 \%$ of the

original observations, and the remaining samples comprise the 'out-of-bag' (OOB) data. Using the trees

grown from a bootstrap sample, each of the independent observations in the OOB data is classified as

either presence or absence and a model prediction error (OOB error) as the percent of incorrectly classed

observations is calculated. Random Forest models are considered one of the most credible statistical

methods for species distribution modelling, and are highly flexible and easy to implement (Elith et al.

2008; Iverson et al. 2011; Laube et al. 2015; Wang et al. 2012).

We evaluated OOB error rates using Brier Score (Brier, 1950), which employs the mean squared

error of the probabilistic model predictions and the true presence or absence in OOB data. We also

evaluated performance using sensitivity, specificity, AUC, and Kappa metrics calculated by comparing

predictions to the actual observations in unseen data (OOB data; Table S4). Random Forest also provides

measures of variable importance defined as the mean decrease in model accuracy (DMA; Altmann et al.,

2010). To reduce prediction bias, we fit a balanced random forest model using the 'sample.fraction'

argument to grow each tree from random samples of the data with an equal number of detections and non-

detections. Because the effect of number of predictors selected at each node was minor, we used the

default square-root of the number of predictors included (Breiman, 2001). By repeated testing, we found

that 500 trees per model generated consistency in model accuracy.

We first predicted the climate niche for resident and breeding song sparrows using the predict

function in the ranger package to produce maps in response to the contemporary, historical, and future 
275 those which were occupied during the breeding period and absent in winter. The resident niche was

276 determined by classifying 'resident' pixels as those which were occupied during both breeding and winter 277 periods, assuming the same individuals are present in both seasons. All niche models were then visualized 278 in ArcGIS (v10.7.1).

\section{Spatial and temporal map comparisons}

To assess agreement of our climate and demographic niche models we first calculated the

over the last half century). To do so, we also classified grid cells by the expected rate of population description of seasonal and spatial climate variation in these regions appear in Fig S5 and Table S6. 
303 Table 1. Predicted response of demographic vital rates to climatic variables, their hypothesized mode of action, and 304 references to the prior results on which predictions are based.

\begin{tabular}{|c|c|c|c|c|c|}
\hline Vital Rate & $\begin{array}{l}\text { Variable } \\
\text { (Abbreviation) }\end{array}$ & Months & Rationale & References & Prediction \\
\hline \multirow[t]{3}{*}{ Survival } & $\begin{array}{l}\text { Degree days }<0^{\circ} \mathrm{C} \\
(\mathrm{DD}<0)\end{array}$ & Dec, Jan, Feb & $\begin{array}{l}\text { Influences energy required } \\
\text { for thermoregulation and } \\
\text { reduces access to food }\end{array}$ & $\begin{array}{l}\text { Arcese, 1989; } \\
\text { Keller et al. 1994; } \\
\text { Ketterson and King } \\
1977\end{array}$ & $\begin{array}{l}\text { Survival rates decrease } \\
\text { as degree days below } \\
\text { freezing increase }\end{array}$ \\
\hline & $\begin{array}{l}\text { Spring precipitation } \\
(\mathrm{PPT}) \text { in } \mathrm{mm}\end{array}$ & Apr, May & $\begin{array}{l}\text { Influences level of } \\
\text { environmental stress and } \\
\text { reduces foraging } \\
\text { opportunities }\end{array}$ & $\begin{array}{l}\text { Öberg et al. 2015; } \\
\text { McDonald et al. } \\
2004\end{array}$ & $\begin{array}{l}\text { Survival rates decrease } \\
\text { with high precipitation } \\
\text { in spring }\end{array}$ \\
\hline & $\begin{array}{l}\text { Summer precipitation } \\
(\mathrm{PPT}) \text { in } \mathrm{mm} \\
\text { Degree days }>18^{\circ} \mathrm{C} \\
(\mathrm{DD}>18)\end{array}$ & Jun, Jul, Aug & $\begin{array}{l}\text { Dry, hot summers reduce } \\
\text { food abundance and may } \\
\text { increase intraspecific } \\
\text { competition for access to } \\
\text { water }\end{array}$ & $\begin{array}{l}\text { Arcese and Smith } \\
\text { 1985; Arcese and } \\
\text { Smith 1988; Smith } \\
\text { et al. } 2006\end{array}$ & $\begin{array}{l}\text { Survival rates decrease } \\
\text { with low precipitation } \\
\text { in late summer/degree } \\
\text { days greater than } 18^{\circ} \mathrm{C}\end{array}$ \\
\hline \multirow[t]{3}{*}{$\begin{array}{l}\text { Reproductive } \\
\text { success }\end{array}$} & $\begin{array}{l}\text { Degree days }<0^{\circ} \mathrm{C} \\
(\mathrm{DD}<0)\end{array}$ & $\begin{array}{l}\text { Jan, Feb, Mar, } \\
\text { April (prior to } \\
\text { breeding) }\end{array}$ & $\begin{array}{l}\text { Influences length of } \\
\text { breeding season }\end{array}$ & $\begin{array}{l}\text { Tarwater and } \\
\text { Arcese 2018; } \\
\text { Wilson and Arcese } \\
2003\end{array}$ & $\begin{array}{l}\text { Reproductive success } \\
\text { decreases as degree } \\
\text { days below freezing } \\
\text { increase }\end{array}$ \\
\hline & $\begin{array}{l}\text { Spring precipitation } \\
(\mathrm{PPT}) \text { in } \mathrm{mm}\end{array}$ & Mar, Apr, May & $\begin{array}{l}\text { Influences level of } \\
\text { environmental stress } \\
\text { during nesting period, } \\
\text { reduces forging } \\
\text { opportunities, and is } \\
\text { correlated with nest } \\
\text { abandonment }\end{array}$ & $\begin{array}{l}\text { Öberg et al. 2015; } \\
\text { Wingfield 1985; } \\
\text { McDonald et al. } \\
\text { 2004; Crombie and } \\
\text { Arcese } 2018\end{array}$ & $\begin{array}{l}\text { Reproductive success } \\
\text { decreases with high } \\
\text { levels of precipitation } \\
\text { in spring }\end{array}$ \\
\hline & $\begin{array}{l}\text { Summer precipitation } \\
(\mathrm{PPT}) \text { in } \mathrm{mm} \\
\text { Degree days }>18^{\circ} \mathrm{C} \\
(\mathrm{DD}>18)\end{array}$ & Jun, July & $\begin{array}{l}\text { Dry, hot summers reduce } \\
\text { food abundance and may } \\
\text { increase intraspecific } \\
\text { competition for access to } \\
\text { water, especially among } \\
\text { fledged young. } \\
\text { May also influence length } \\
\text { of breeding season }\end{array}$ & $\begin{array}{l}\text { Arcese and Smith } \\
\text { 1985; Arcese and } \\
\text { Smith 1988; Smith } \\
\text { et al. 2006; } \\
\text { Tarwater and } \\
\text { Arcese } 2018\end{array}$ & $\begin{array}{l}\text { Reproductive success } \\
\text { decreases with low } \\
\text { precipitation in late } \\
\text { summer/degree days } \\
\text { greater than } 18^{\circ} \mathrm{C}\end{array}$ \\
\hline
\end{tabular}




\section{Results}

309 Demographic models

310 We predicted the growth rate $(\lambda)$ of song sparrow populations in western North America using a

311 deterministic model based on 48 years of data of juvenile and adult survival $\left(\mathrm{S}_{\mathrm{j}}, \mathrm{S}_{\mathrm{a}}\right)$ and reproductive

312 success (RS) and relationships between climatic conditions in our focal population. Eight climate

313 variables hypothesized to influence demography in our focal population accounted for 47,44 and $56 \%$ of

314 variation in annual $\mathrm{S}_{\mathrm{j}}, \mathrm{S}_{\mathrm{a}}$, and RS observed, respectively (Table 1, S1, S3). $\mathrm{S}_{\mathrm{j}}$ was predicted to increase

315 with rainfall in August $(\beta \pm \mathrm{SE}$; Aug PPT $=0.254 \pm 0.105)$ and slightly with freezing temperature in

316 December (Dec DD $<0=0.190 \pm 0.109)$, but to decline with increasing heat in July (Jul DD $>18=$ -

$\left.3170.390 \pm 0.125 ;(\mathrm{Jul} \mathrm{DD}>18)^{2}=0.195 \pm 0.133\right)$ and freezing temperatures February $($ Feb $\mathrm{DD}<0=0.057$

$\left.318 \pm 0.137 ;[\text { Feb DD }<0]^{2}=-0.457 \pm 0.106\right) . S_{a}$ was similarly predicted to increase with rainfall in August

319 (Aug PPT $=0.134 \pm 0.059$ ) and freezing temperatures in December, to but decline in with freezing

320 temperatures in February $\left(\right.$ Dec DD $<0=0.112 \pm 0.061 ;$ Feb DD $<0=-0.065 \pm 0.086 ;(\text { Feb DD }<0)^{2}=-$

$3210.331 \pm 0.082)$. RS was predicted to increase with increasing warmth and precipitation in spring (Jun DD

$322>18=0.207 \pm 0.059 ;$ Mar PPT $=0.151 \pm 0.055 ;$ Jun PPT $=0.175 \pm 0.059)$, factors also influencing the

323 start and duration of breeding.

324

325 Climate niche models

326 Predicted resident and migrant climate niche models displayed high accuracy (OOB error: $15.5 \%$ and

$32713.9 \%$ ), sensitivity ( $81.1 \%$ and $83.0 \%$ ), and specificity (78.4\% and 80.3\%), respectively (Table S4).

328 Models to predict the resident and migrant climate niches of song sparrows in western North America

329 were trained using 10 climate variables and evaluated by model performance and classification error.

330 Variables reflecting ambient and extreme temperatures had the largest influence on model accuracy in our

331 resident niche model (e.g., DD > 5, Tmax, Tmin, Tave) with DMA ranging from 11.5 to $12.7 \%$ (Fig. S2).

332 The predicted migrant niche also depended strongly on local climate, especially temperature in late winter 
333 to early spring (Fig. S2; Tmax, DD > 5, Tmin, DD > 18; DMA = 12.4 to $13.5 \%$.) Precipitation also

334 influenced resident and migrant niches strongly (e.g., see below; Fig. S2; DMA = 10.6 and 12.2\%, 335 respectively).

336 However, variables used to develop climate niche models affected migrant and resident niche

337 differently over our study area in western North America (Fig S5). In all cases, warmer winter

338 temperatures prevailed in the resident versus migrant niche, but these differences were much smaller in

339 California than Alaska, causing a statistical interaction between location and migratory status (Table S6).

340 In contrast, winter precipitation was higher in the migrant than resident niche in $\mathrm{AK}$ and $\mathrm{BC}$ whereas an

341 opposite pattern prevailed in niche CA (Table S6). Variables reflecting heat load in spring also influenced

342 resident and migrant climate niches unequally. For example, degree-days of warming (DD > 18) in the

343 migrant niche in CA exceeded values recorded in the resident niche. Warming was also higher in the

344 resident than migrant niche in BC but similar in migrant and resident niches in AK (Table S6).

\section{Spatial agreement of demographic and climate niches}

347 The parallel effects of climate on the demography of our focal population and modeled distributions of 348 resident and migratory populations in western North America led to strong agreement of the predicted 349 niches in Cartesian space between our demographic and climate niche models in the region of our focal 350 population (BC; 0.728; Fig. 1c, f). However, agreement among predictions was slightly to much weaker 351 at the northern $(\mathrm{AK} ; 0.627)$ and southern $(\mathrm{CA} ; 0.259)$ extents of the study area, respectively. Spatial 352 correlations between the predicted distributions of resident and migratory sparrows also declined as the 353 Euclidean distance from our focal population increased $(r=-0.24 \pm 0.02)$, as expected if locally adapted 354 populations respond to climatic conditions differently than those resident year-round in our focal study 355 population.

Agreement of our climate and demographic niche models also declined as climatic conditions in 357 our focal population diverged from those experienced by song sparrows elsewhere in western North 
America. Across western North American variation in climate space was largely accounted for by PC1

(56.2\%; Table S5), reflecting differences in 'continentality;' e.g., coastal areas with positive values of

PC1 experience much less variation in annual temperature and precipitation than montane, high plains,

values; Fig. S3).

Strong spatial correlations between the demography and predicted distribution of resident and

(PC1, Fig S4) and the spatial overlap of the predictions of demographic and climate niche models in the

region surrounding our focal population (bin 2: $r=0.78 \pm 0.01$ ). However, as predicted, we observed

continentality was very high (bin $1: r=0.53 \pm 0.02$ ), and in the southern region of our study area $(\mathrm{CA})$

where variation in continentality was less but variation in aridity was high (bin 3: $r=0.32 \pm 0.02$ ).

Despite accounting for a substantial fraction of variation in climate over the study area, PC2 was weakly related to the predicted ranges of resident and migrant song sparrows based on our climate niche model (Fig S4).

\section{Historical and future variation in the spatial distribution of the climate niche}

376 General agreement of our demographic and climate-based niche models allowed us to ask how migratory

temperatures at our focal population averaged $0.9^{\circ} \mathrm{C}$ less than conditions in $2010-2018$, but still $3.1^{\circ} \mathrm{C}$ less 
383 we expected that climate warming has facilitated range expansion by song sparrows, particularly those

384 displaying resident life histories.

385 In support of our predictions, the combined area of the resident and migrant song sparrow niches

386 in the BC region was predicted to have increased by $27.7 \%\left(39,668 \mathrm{~km}^{2}\right.$; Fig. $2 \mathrm{a}$, b) and $24.1 \%(36,309$

387 km²; (Fig. 2d, e) from 1901-1910 to present (demographic and climate niche model, respectively). The

388 demographic and climate niche model predicted further increases of $27.4 \%\left(50,003 \mathrm{~km}^{2}\right.$; Fig. $\left.2 \mathrm{~b}, \mathrm{c}\right)$ and

$38910.1 \%\left(18,511 \mathrm{~km}^{2}\right.$; Fig. 2e, f), respectively, given climate in 2070-2100. Similarly, the resident niche

390 was predicted to have increased by $36.3 \%\left(24,467 \mathrm{~km}^{2}\right.$; Fig. $\left.2 \mathrm{a}, \mathrm{b}\right)$ from the historical to present period

391 under our demographic model, or by $38.8 \%\left(37,471 \mathrm{~km}^{2}\right.$; Fig. $2 \mathrm{~d}$, e) in climate niche model. The resident

392 niche was also projected to increase by $12.8 \%\left(17,015 \mathrm{~km}^{2}\right.$; Fig. $\left.2 \mathrm{e}, \mathrm{f}\right)$ from the present to future period

393 by our climate niche model, but by $69.1 \%$ under our demographic niche model $\left(63,384 \mathrm{~km}^{2}\right.$; Fig. 2 b, c).

394 Demographic and climate models also predicted upward expansions in elevation range for song sparrows,

395 with the mean elevation of resident populations rising $171 \mathrm{~m}$ over 200 years (i.e., 1900 to 2100 ; historical

$396=365 \mathrm{~m}$, current $=475 \mathrm{~m}$, future $=536 \mathrm{~m})$ according to our climate model versus 258 meters $($ historical $=$

$397240 \mathrm{~m}$, current $=281 \mathrm{~m}$, future $=498 \mathrm{~m}$ ) by our demographic model, confirming close correspondence of

398 these predictive models proximal to our focal study population. 
bioRxiv preprint doi: https://doi org/10.1101/2021.09.01.458412; this version posted September 3, 2021. The copyright holder for this preprint (which was not certified by peer review) is the author/funder, who has granted bioRxiv a license to display the preprint in perpetuity. It is made available under aCC-BY-ND 4.0 International license.

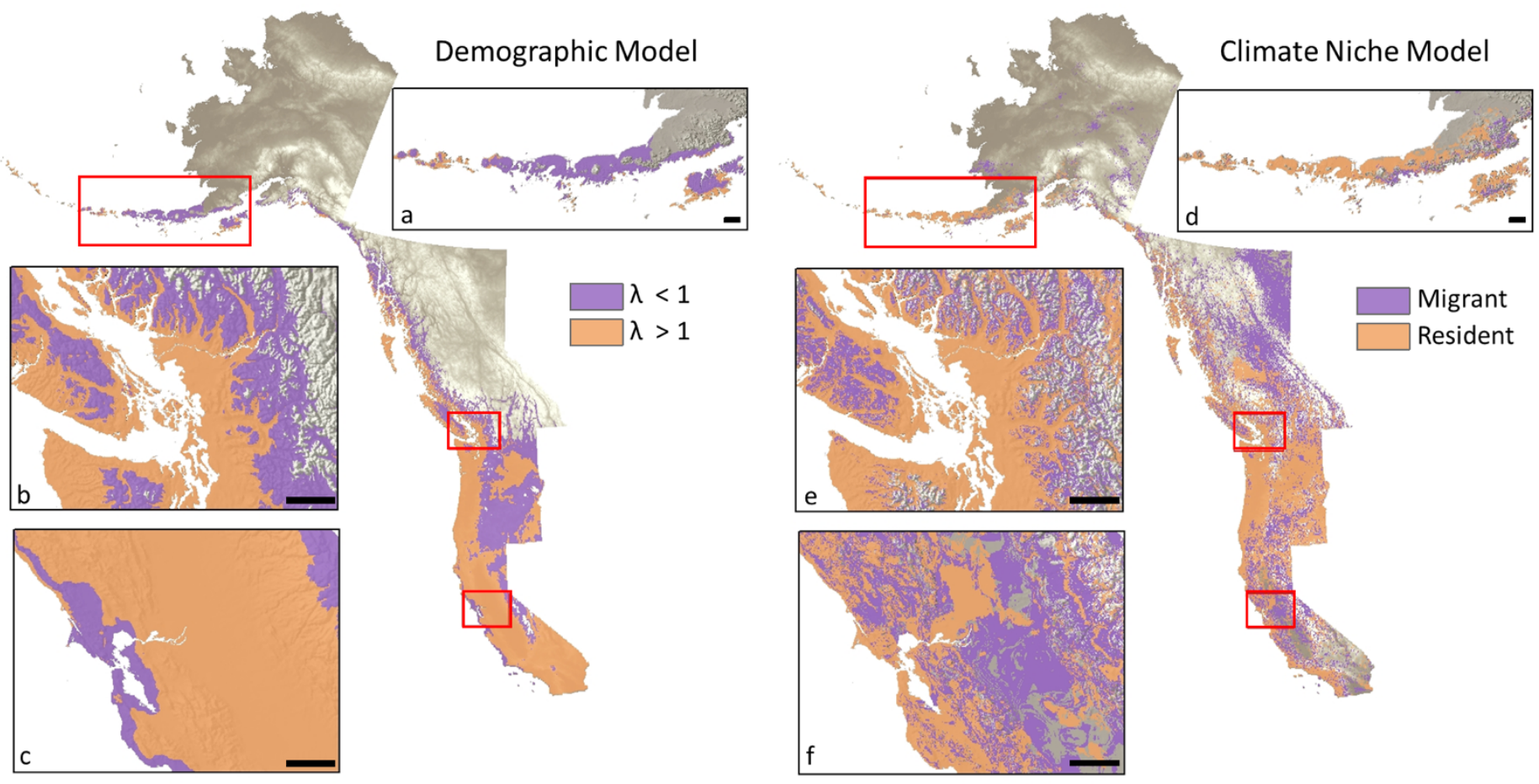

400 Figure 1. Present-day ranges of the expected population growth wherein the migrant demographic niche is indicated 401 in purple $(\lambda<1)$, and resident demographic niche is indicated in orange $(\lambda>1)$ predicted using demographic models 402 (insets a-c), and migratory (purple) and resident song sparrow populations (orange) predicted using climate niche 403 models (insets d-f; see Methods). AK (inset a and d; Aleutian Islands, AK), BC (inset b and e; Georgia Basin, BC), 404 and CA (inset $\mathrm{c}$ and f; San Francisco Bay, CA) regions highlight areas wherein the observed ranges are more and 405 406 less similar. Climate data was acquired from ClimateNA (version 6.00; Wang et al. 2016). Scale bar: 50km. 


\section{Climate Niche} Model

$\square$ Migrant
$\square$ Resident

Figure 2. Projected distribution of song sparrows for past (1901-1910; a, d), current (2010-2018; b, e) and future (2070-2100 under scenario RCP 4.5; c, f) using two modelling approaches: demographic modelling (GLM; a-c), and climate niche modelling (Random Forest; $d-f$ ) for the BC region. In the demographic models, the migrant niche $(\lambda<$ $1)$ is indicated in purple and resident niche $(\lambda>1)$ in orange, and in the climate niche models the migrant niche is shown in purple and resident niche in orange. Climate data was acquired from ClimateNA (version 6.00; Wang et al. 2016). 


\section{Discussion}

432 Predicting how species distribution may shift in response to climate change will depend in part on how

433 life-history traits such as seasonal migration versus residence influence species occupancy in response to

434 seasonality and resource availability via their influence on individual fitness and population demography

435 (e.g., Reid et al. 2018, Visty et al. 2018, Acker et al., 2021a; 2021b). Accordingly, we addressed

436 uncertainties in the development and application of species distribution models, their empirical basis, and

437 the reliability of their predictions whilst also exploring the potential for variation in migration to facilitate

438 climate adaptation in a highly polytypic, mobile species. We found substantial agreement in the

439 predictions of demographic and climate niche models in the region encompassing of our focal study

440 population (BC), but lower agreement in areas experiencing different climatic conditions. Our results thus

441 support the idea that climate niche models based on species occupancy and long-term climate averages

442 can reproduce the predictions of detailed, empirical models that link demographic performance to species

443 distribution and migration via space for time substitution. In contrast, our efforts to extrapolate the

444 predicted effects of climate on the demography of our focal study population to song sparrows over their

445 range in western North America revealed mismatches that indicate that the climatic factors driving

446 demography in our focal population differ from those driving the demography of populations in CA and

447 AK. However, our results also suggest that climate has and will continue play a key role affecting the

448 distribution of song sparrows via its influence on demography, and that variation in migration may

449 facilitate climate adaptation by influencing the composition of populations with respect to migratory

450 phenotype and population growth. Taken together, these findings highlight the potential role of life

451 history evolution in climate adaptation while also pointing to limits in our ability to predict long-term

452 change in species distributions and mechanisms involved. We now develop these results with respect to

453 our initial goals. 
456 We found strong agreement between the mapped predictions of empirical models designed to represent

457 the contemporary distributions of resident and migrant song sparrow populations, given assumptions

458 about their response to spatial and temporal variation in climate and its influence on population growth

459 (Fig. 1). These results strongly support the general hypothesis that climate plays a key role in the

460 demography, distribution, and life history of species (Hutchinson, 1957). More importantly, they extend

461 understanding by demonstrating that empirical demographic models driven by climatic conditions can

462 predict migratory phenotype given historical, current, or future climatic conditions (Fig. 2).

Dybala et al. (2013) suggested that the climate niche of song sparrows at a long-term monitoring

site in coastal California was strongly influenced by winter temperature and precipitation in the preceding

wet season via their effects on survival and population growth. Our demographic model predicted a

466 declining population growth rate $(\lambda=0.80)$ in coastal California, similar to Dybala et al.'s $(2013)$

467 prediction given averaged climatic conditions $(\lambda=0.88)$. However, because we arbitrarily classified

468 populations predicted to decline $(\lambda<1)$ based on local climate and modeled relationships between

469 demography and climate in our focal population, our demographic niche model predicted that this coastal

470 California population should migrate, whereas our climate niche model accurately predicted their status

471 as year-round residents. It is plausible that some song sparrow populations in coastal California exist as

472 metapopulations comprising a mix of migratory phenotypes. Although, these comparisons suggest our

473 empirical demographic niche model under-predicted the range of resident song sparrows in western North

474 America, they generally support suggestions that climate niche models can be used to elucidate factors

475 contributing to variation in the historical, contemporary, and future distributions of partial migrant

476 species.

Across western North America our climate and demographic niche models yielded moderate to

excellent predictions of the migratory status of song sparrow populations (Fig. 1; Table S3; S4). In

479 particular, models built on an a priori understanding of the effects of climate on local survival,

480 reproduction, and population growth predicted the observed distribution of resident and migratory 
481 populations in the $\mathrm{BC}$ region with high precision. This supports the hypothesis that variation in the

482 occurrence of seasonal migration represents an adaptive response to temporal variation in climate and its

483 influence on resource availability and osmotic and/or thermal stress. Moreover, the close correspondence

484 of our empirical climate niche model with observed patterns of spatial variation seasonal migration in BC

485 imply that this variation is shaped by natural selection (e.g., Arcese et al., 2002; Peters et al., 2017; Reid

486 et al., 2018; Delmore et al., 2020).

\section{Spatio-temporal shifts in resident and migrant niches}

489 Links between climate, demography, and distribution in BC allowed us to also predict that climate

warming in the last century should have facilitated range expansion by song sparrows expressing resident

phenotypes as the amelioration of winter cold and relaxed its effects on juvenile and adult survival (e.g,

Arcese et al. 1992). Similar examples of range expansion and upward shifts in elevation in response to

et al., 2005; plants, Holzinger et al., 2008; mammals, Moritz et al., 2008). Although song sparrows have

niche model suggests that a population comprised of residents would decline rapidly given historical

climatic conditions due to a much higher frequency of freezing temperatures in winter. We therefore

currently the case in song sparrow populations breeding above $500 \mathrm{~m}$ elevation in BC (Fig. 2, our unpubl.

migratory to residential phenotype has occurred at Interpont, Ohio, where Nice (1933) used color-banded

birds to confirm the migratory status of all but a single male song sparrow in the $1930 \mathrm{~s}$, but wherein most

or all birds now reside year-round (Chris Tonra, pers. comm.). Historical records in British Columbia also 
Overall, the distribution of resident song sparrow populations predicted by our models has

expanded substantially since historical surveys (Fig. 1), implying a marked expansion over the last

century. Similarly, Visty et al. (2018) reported that fox sparrows (Passerella unalaschcensis), formerly an

obligate migrant throughout its range, established year-round residence on Mandarte Is. after 1960-63,

when Tompa (1963) initiated our song sparrow study. Interestingly, Visty et al. (2018) reported that

511 resident fox sparrows produced more broods, and displayed higher survival and population growth rates

512 on Mandarte Is. than migrant populations studied to date, suggesting that higher relative fitness in birds

513 displaying resident versus migrant phenotypes facilitated an expansion of the breeding range.

\section{Local adaptation}

In European shags (Phalacrocorax aristotelis), harsh climatic events in winter contributed to

mortality and influenced natural selection on the migratory phenotype of individuals, supporting the idea

that micro-evolutionary processes can influence the composition of populations with respect to migratory

phenotype and affect the breeding distribution of species (Acker et al., 2021a; 2021b). Our results

underscore this idea by demonstrating thematic links between climatic, population demography, species

distribution, and the evolution of seasonal migration in response to historic and ongoing climate change

(Aitken et al., 2008; Sexton et al., 2009; Hendry et al., 2018; Bay et al., 2018). Specifically, we suggest

that variation in migration behavior represents one route by which mobile species can adapt to rapid

climate change, particularly in partial migrants subject to climatic limits on survival and/or reproduction.

Song sparrows are among the most polytypic vertebrates known (Aldrich, 1984; Arcese et al.,

2002; Patten \& Pruett, 2009) and vary markedly in migration behavior and correlated behavioral,

morphological and physiological traits including body dimensions (Pruett \& Winker, 2010), clutch size

(Johnston, 1954), and osmoregulatory capacity (Mikles et al., 2020). Song sparrows also vary predictably

in traits widely recognized as adaptations to climatic variation in seasonality and primary production 
531 traits linked to fecundity, parental effort, and longevity (Arcese, 1989; Arcese et al., 2002; Germain \&

532 Arcese, 2014; Tarwater \& Arcese, 2017; Reid \& Arcese, 2020). Because many such traits have an

533 additive genetic basis (e.g., Schluter \& Smith, 1986; Wolak \& Reid, 2016; Reid \& Arcese, 2020), it is

534 plausible that spatial variation in natural selection has contributed to heritable variation in migratory

535 phenotype, as extensively described in European blackcaps (Sylvia atricapilla; e.g., Berthold, 1991;

536 Berthold \& Pulido, 1994; Delmore et al., 2020). If so, the pace of adaptation to climate warming in song

537 sparrows might first be measured as the rate by which residency has become established in local

538 populations known to have been migrants historically, and secondarily by estimating the rate of change in

539 allele frequencies at functional loci (Rellstab et al., 2016; Capblancq et al., 2020). Phenotypic changes in

540 migration may also arise plastically and influence subsequent genetic change (Coppack \& Pulido, 2004;

541 Pulido, 2007; Teplitsky \& Millien, 2014). Quantitative genetic approaches (Kruuk, 2004; Wolak et al.,

542 2018; Reid et al., 2021) to estimate the genetic basis of partial migration and pedigree-based comparison

543 of individuals displaying different migratory tactics should also help elucidate the contributions of

544 phenotypic plasticity versus micro-evolution in local adaptation to rapid environmental change.

546 Conclusions

547 The ability of song sparrows to persist over a wide range of climatic conditions in western North America

548 indicates a broad tolerance for a diverse range of factors with the potential to limit individual fitness and

549 population growth. By engaging in seasonal migration from sites where residents are unlikely to persist

550 year-round, song sparrows encompass a larger range in North America than could otherwise be

551 accommodated. The rapid evolution of populations comprised of migrant, partial migrant, or resident

552 song sparrows, as evidenced by transitions to residency in areas subject to climate warming, thus appears

553 to be a common mechanism by which song sparrows and other mobile species are adapting to local and

554 global climate change. However, regardless of taxa, phenotypic change in migratory status is likely to be

555 accompanied by changes in a suite of physiological, morphological, and behavioral traits influenced by 
556 plastic and genetic pathways. Consequently, predicting the speed at which populations can respond to

557 change still requires a better understanding of the loci involved, the influence of natural selection on

558 standing variation in focal and correlated traits, and the genetic structure of such populations. Addressing

559 such uncertainties could advance conservation planning, but is challenging in the absence of robust, long-

560 term studies capable of elucidating the mechanisms underlying local adaptation to climate.

561

562

563

564

565

566

567

568

569

570

571

572

573

574

575

576

577

578

579

580

581

582

583

584

585

586

587

588

589

590

591

592

593

594

595

596

597

598

599 


\section{References}

601

602

603

604

605

606

607

608

609

610

611

612

613

614

615

616

617

618

619

620

621

622

623

624

625

626

627

628

629

630

631

632

633

634

635

636

637

638

639

640

641

642

643

644

645

646

647

Acker, P., Burthe, S. J., Newell, M. A., Grist, H., Gunn, C., Harris, M. P., Payo-Payo, A., Swann, R., Wanless, S., Daunt, F., \& Reid, J. M. (2021a). Episodes of opposing survival and reproductive selection cause strong fluctuating selection on seasonal migration versus residence. Proceedings of the Royal Society B: Biological Sciences, 288(1951), 20210404. https://doi.org/10.1098/rspb.2021.0404

Acker, P., Daunt, F., Wanless, S., Burthe, S. J., Newell, M. A., Harris, M. P., Grist, H., Sturgeon, J., Swann, R. L., Gunn, C., Payo-Payo, A., \& Reid, J. M. (2021b). Strong survival selection on seasonal migration versus residence induced by extreme climatic events. Journal of Animal Ecology, 13652656.13410. https://doi.org/10.1111/1365-2656.13410

Aitken, S. N., Yeaman, S., Holliday, J. A., Wang, T., \& Curtis-McLane, S. (2008). Adaptation, migration or extirpation: climate change outcomes for tree populations. Evolutionary Applications. https://doi.org/10.1111/j.1752-4571.2007.00013.x

Aldrich, J. W. (1984). Ecogeographical Variation in Size and Proportions of Song Sparrows (Melospiza melodia). Ornithological Monographs, 35, iii-134. https://doi.org/10.2307/40166779

Altmann, A., Toloşi, L., Sander, O., \& Lengauer, T. (2010). Permutation importance: A corrected feature importance measure. Bioinformatics. https://doi.org/10.1093/bioinformatics/btq134

Amatulli, G., Domisch, S., Tuanmu, M. N., Parmentier, B., Ranipeta, A., Malczyk, J., \& Jetz, W. (2018). Data Descriptor: A suite of global, cross-scale topographic variables for environmental and biodiversity modeling. Scientific Data. https://doi.org/10.1038/sdata.2018.40

Andrewartha, H. G., \& Birch, L. C. (1954). The distribution and abundance of animals. The Distribution and Abundance of Animals., Edn 1.

Angert, A. L., Crozier, L. G., Rissler, L. J., Gilman, S. E., Tewksbury, J. J., \& Chunco, A. J. (2011). Do species' traits predict recent shifts at expanding range edges? In Ecology Letters.

https://doi.org/10.1111/j.1461-0248.2011.01620.x

Arcese, P., \& Smith, J. N. M. (1985). Phenotypic Correlates and Ecological Consequences of Dominance in Song Sparrows. The Journal of Animal Ecology. https://doi.org/10.2307/4380

Arcese, Peter. (1989). Intrasexual competition, mating system and natal dispersal in song sparrows. Animal Behaviour, 38(6), 958-979. https://doi.org/10.1016/S0003-3472(89)80137-X

Arcese, Peter, \& Smith, J. N. M. (1988). Effects of Population Density and Supplemental Food on Reproduction in Song Sparrows. The Journal of Animal Ecology. https://doi.org/10.2307/4768

Arcese, Peter, Smith, J. N. M., Hochachka, W. M., Rogers, C. M., \& Ludwig, D. (1992). Stability, Regulation, and the Determination of Abundance in an Insular Song Sparrow Population. Ecology, 73(3), 805-822. https://doi.org/10.2307/1940159

Arcese, Peter, Sogge, M. K., Marr, A. B., \& Patten, M. A. (2002). Song Sparrow (Melospiza melodia). In A. F. Poole \& F. B. Gill (Eds.), The Birds of North America. The Birds of North America, Inc. https://doi.org/10.2173/bna.704

Avgar, T., Street, G., \& Fryxell, J. M. (2014). On the adaptive benefits of mammal migration. In Canadian Journal of Zoology (Vol. 92, Issue 6, pp. 481-490). National Research Council of Canada. https://doi.org/10.1139/cjz-2013-0076

Bay, R. A., Harrigan, R. J., Underwood, V. Le, Gibbs, H. L., Smith, T. B., \& Ruegg, K. (2018). Genomic signals of selection predict climate-driven population declines in a migratory bird. Science, 359(6371), 83-86. https://doi.org/10.1126/science.aan4380

Bayly, M. J., \& Angert, A. L. (2019). Niche models do not predict experimental demography but both suggest dispersal limitation across the northern range limit of the scarlet monkeyflower (Erythranthe cardinalis). Journal of Biogeography. https://doi.org/10.1111/jbi.13609

Bell, G. (2017). Evolutionary Rescue. Annual Review of Ecology, Evolution, and Systematics, 48(1), 605627. https://doi.org/10.1146/annurev-ecolsys-110316-023011 
648

649

650

651

652

653

654

655

656

657

658

659

660

661

662

663

664

665

666

667

668

669

670

671

672

673

674

675

676

677

678

679

680

681

682

683

684

685

686

687

688

689

690

691

692

693

694

695

696

Berthold, P., \& Pulido, F. (1994). Heritability of migratory activity in a natural bird population.

Proceedings of the Royal Society of London. Series B: Biological Sciences, 257(1350), 311-315. https://doi.org/10.1098/RSPB.1994.0131

Berthold, Peter. (1991). Genetic control of migratory behaviour in birds. In Trends in Ecology and Evolution (Vol. 6, Issue 8, pp. 254-257). https://doi.org/10.1016/0169-5347(91)90072-6

Bontrager, M., \& Angert, A. L. (2019). Gene flow improves fitness at a range edge under climate change. Evolution Letters. https://doi.org/10.1002/evl3.91

Breiman, L. (2001). Random forests. Machine Learning, 45, 5-32. https://doi.org/10.1023/A:1010933404324

Brier, G. (1950). Verification of forecasts expressed in terms of probability. Monthly Weather Review. https://doi.org/10.1175/1520-0493(1950)078<0001:vofeit $>2.0$. co;2

Capblancq, T., Fitzpatrick, M. C., Bay, R. A., Exposito-Alonso, M., \& Keller, S. R. (2020). Genomic Prediction of (Mal)Adaptation across Current and Future Climatic Landscapes. In Annual Review of Ecology, Evolution, and Systematics (Vol. 51, pp. 245-269). Annual Reviews Inc. https://doi.org/10.1146/annurev-ecolsys-020720-042553

Chapman, B. B., Hulthén, K., Brodersen, J., Nilsson, P. A., Skov, C., Hansson, L. A., \& Brönmark, C. (2012). Partial migration in fishes: Causes and consequences. Journal of Fish Biology, 81(2), 456478. https://doi.org/10.1111/j.1095-8649.2012.03342.x

Charmantier, A., McCleery, R. H., Cole, L. R., Perrins, C., Kruuk, L. E. B., \& Sheldon, B. C. (2008). Adaptive phenotypic plasticity in response to climate change in a wild bird population. Science. https://doi.org/10.1126/science. 1157174

Chen, I. C., Hill, J. K., Ohlemüller, R., Roy, D. B., \& Thomas, C. D. (2011). Rapid range shifts of species associated with high levels of climate warming. Science. https://doi.org/10.1126/science.1206432

Coppack, T., \& Pulido, F. (2004). Photoperiodic Response and the Adaptability of Avian Life Cycles to Environmental Change. Advances in Ecological Research, 35, 131-150. https://doi.org/10.1016/S0065-2504(04)35007-5

Crombie, M. D., \& Arcese, P. (2018). Temporal variation in the effects of individual and environmental factors on nest success. The Auk, 135(2), 326-341. https://doi.org/10.1642/auk-17-189.1

Delmore, K., Illera, J. C., Pérez-Tris, J., Segelbacher, G., Ramos, J. S. L., Durieux, G., Ishigohoka, J., \& Liedvogel, M. (2020). The evolutionary history and genomics of european blackcap migration. ELife, 9. https://doi.org/10.7554/eLife.54462

Dingle, H. (2014). Migration: the biology of life on the move. Migration: The Biology of Life on the Move. https://doi.org/10.2307/2404896

Dybala, K. E., Eadie, J. M., Gardali, T., Seavy, N. E., \& Herzog, M. P. (2013). Projecting demographic responses to climate change: adult and juvenile survival respond differently to direct and indirect effects of weather in a passerine population. Global Change Biology, 19(9), 2688-2697. https://doi.org/10.1111/gcb.12228

Elith, J., Leathwick, J. R., \& Hastie, T. (2008). A working guide to boosted regression trees. In Journal of Animal Ecology. https://doi.org/10.1111/j.1365-2656.2008.01390.x

Elith, Jane, \& Leathwick, J. R. (2009). Species distribution models: Ecological explanation and prediction across space and time. Annual Review of Ecology, Evolution, and Systematics, 40, 677-697. https://doi.org/10.1146/annurev.ecolsys.110308.120159

Fannin, J. (1891). Checklist of British Columbia Birds. Richard Wolfenden.

Gaston, K. J. (2003). The Structure and Dynamics of Geographic Ranges. In Oxford University Press.

Germain, R. R., \& Arcese, P. (2014). Distinguishing individual quality from habitat preference and quality in a territorial passerine. Ecology. https://doi.org/10.1890/13-0467.1

Ghalambor, C. K., McKay, J. K., Carroll, S. P., \& Reznick, D. N. (2007). Adaptive versus non-adaptive phenotypic plasticity and the potential for contemporary adaptation in new environments. Functional Ecology, 21(3), 394-407. https://doi.org/10.1111/j.1365-2435.2007.01283.x 
697

698

699

700

701

702

703

704

705

706

707

708

709

710

711

712

713

714

715

716

717

718

719

720

721

722

723

724

725

726

727

728

729

730

731

732

733

734

735

736

737

738

739

740

741

742

743

744

745
Gillings, S., Balmer, D. E., \& Fuller, R. J. (2015). Directionality of recent bird distribution shifts and climate change in Great Britain. Global Change Biology. https://doi.org/10.1111/gcb.12823

Grant, P. R., \& Grant, B. R. (2006). Evolution of character displacement in Darwin's finches. Science. https://doi.org/10.1126/science. 1128374

Hendry, A. P., Schoen, D. J., Wolak, M. E., \& Reid, J. M. (2018). The Contemporary Evolution of Fitness. Annual Review of Ecology, Evolution, and Systematics. https://oi.org/10.1146/annurevecolsys-110617-062358

Hickling, R., Roy, D. B., Hill, J. K., \& Thomas, C. D. (2005). A northward shift of range margins in British Odonata. Global Change Biology, 11(3), 502-506. https://doi.org/10.1111/j.13652486.2005.00904.x

Holzinger, B., Hülber, K., Camenisch, M., \& Grabherr, G. (2008). Changes in plant species richness over the last century in the eastern Swiss Alps: Elevational gradient, bedrock effects and migration rates. Plant Ecology, 195(2), 179-196. https://doi.org/10.1007/s11258-007-9314-9

Hutchinson, G. E. (1957). Cold spring harbor symposium on quantitative biology. Concluding Remarks, $22,415-427$.

IPCC. (2014). Climate Change 2014: Synthesis Report. Contribution of Working Groups I, II and III to the Fifth Assessment Report of the Intergovernmental Panel on Climate Change. In IPCC.

Iverson, L. R., Prasad, A. M., Matthews, S. N., \& Peters, M. P. (2011). Lessons Learned While Integrating Habitat, Dispersal, Disturbance, and Life-History Traits into Species Habitat Models Under Climate Change. Ecosystems, 14(6), 1005-1020. https://doi.org/10.1007/s10021-011-9456-4

Johnston, A., Hochachka, W., Strimas-Mackey, M., Gutierrez, V. R., Robinson, O., Miller, E., Auer, T., Kelling, S., \& Fink, D. (2019). Best practices for making reliable inferences from citizen science data: case study using eBird to estimate species distributions. BioRxiv. https://doi.org/10.1101/574392

Johnston, R. F. (1954). Variation in Breeding Season and Clutch Size in Song Sparrows of the Pacific Coast. The Condor, 56(5), 268-273. https://doi.org/10.2307/1364850

Keller, L. F., Arcese, P., Smith, J. N. M., Hochachka, W. M., \& Stearns, S. C. (1994). Selection against inbred song sparrows during a natural population bottleneck. Nature, 372(6504), 356-357. https://doi.org/10.1038/372356a0

Ketterson, E. D., \& King, J. R. (1977). Metabolic and Behavioral Responses to Fasting in the Whitecrowned Sparrow (Zonotrichia leucophrys gambelii). Physiological Zoology. https://doi.org/10.1086/physzool.50.2.30152551

Kruuk, L. E. B. (2004). Estimating genetic parameters in natural populations using the "animal model." In Philosophical Transactions of the Royal Society B: Biological Sciences (Vol. 359, Issue 1446, pp. 873-890). Royal Society. https://doi.org/10.1098/rstb.2003.1437

La Sorte, F. A., \& Thompson, F. R. (2007). Poleward shifts in winter ranges of North American birds. Ecology, 88(7), 1803-1812. https://doi.org/10.1890/06-1072.1

Lameris, T. K., Bennett, J. R., Blight, L. K., Giesen, M., Janssen, M. H., Schaminée, J. J. H. J., \& Arcese, P. (2016). A century of ecosystem change: Human and seabird impacts on plant species extirpation and invasion on islands. PeerJ. https://doi.org/10.7717/peerj.2208

Laube, I., Graham, C. H., \& Böhning-Gaese, K. (2015). Niche availability in space and time: Migration in Sylvia warblers. Journal of Biogeography. https://doi.org/10.1111/jbi.12565

Liedvogel, M., Åkesson, S., \& Bensch, S. (2011). The genetics of migration on the move. In Trends in Ecology and Evolution (Vol. 26, Issue 11, pp. 561-569). Elsevier Current Trends.

https://doi.org/10.1016/j.tree.2011.07.009

Mason, L. R., Green, R. E., Howard, C., Stephens, P. A., Willis, S. G., Aunins, A., Brotons, L., Chodkiewicz, T., Chylarecki, P., Escandell, V., Foppen, R. P. B., Herrando, S., Husby, M., Jiguet, F., Kålås, J. A., Lindström, Å., Massimino, D., Moshøj, C., Nellis, R., ... Gregory, R. D. (2019). Population responses of bird populations to climate change on two continents vary with species' 
ecological traits but not with direction of change in climate suitability. Climatic Change, 157, 337352. https://doi.org/10.1007/s10584-019-02549-9

McDonald, P. G., Olsen, P. D., \& Cockburn, A. (2004). Weather dictates reproductive success and survival in the Australian brown falcon Falco berigora. Journal of Animal Ecology, 73(4), 683-692. https://doi.org/10.1111/j.0021-8790.2004.00842.x

Mikles, C. S., Aguillon, S. M., Chan, Y. L., Arcese, P., Benham, P. M., Lovette, I. J., \& Walsh, J. (2020). Genomic differentiation and local adaptation on a microgeographic scale in a resident songbird. Molecular Ecology, 29(22), 4295-4307. https://doi.org/10.1111/mec.15647

Miller, A. H. (1956). ECOLOGIC FACTORS THAT ACCELERATE FORMATION OF RACES AND SPECIES OF TERRESTRIAL VERTEBRATES. Evolution, 10(3), 262-277. https://doi.org/10.1111/j.1558-5646.1956.tb02851.x

Møller, A. P., Jokimäki, J., Skorka, P., \& Tryjanowski, P. (2014). Loss of migration and urbanization in birds: A case study of the blackbird (Turdus merula). Oecologia, 175(3), 1019-1027.

https://doi.org/10.1007/s00442-014-2953-3

Moritz, C., Patton, J. L., Conroy, C. J., Parra, J. L., White, G. C., \& Beissinger, S. R. (2008). Impact of a century of climate change on small-mammal communities in Yosemite National Park, USA. Science, 322(5899), 261-264. https://doi.org/10.1126/science.1163428

Nice, M. M. (1933). Migratory Behavior in Song Sparrows. The Condor, 35(6), 219-224. https://doi.org/10.2307/1363765

Nicotra, A. B., Atkin, O. K., Bonser, S. P., Davidson, A. M., Finnegan, E. J., Mathesius, U., Poot, P., Purugganan, M. D., Richards, C. L., Valladares, F., \& van Kleunen, M. (2010). Plant phenotypic plasticity in a changing climate. In Trends in Plant Science.

https://doi.org/10.1016/j.tplants.2010.09.008

Öberg, M., Arlt, D., Pärt, T., Laugen, A. T., Eggers, S., \& Low, M. (2015). Rainfall during parental care reduces reproductive and survival components of fitness in a passerine bird. Ecology and Evolution, 5(2), 345-356. https://doi.org/10.1002/ece3.1345

Parmesan, C. (2006). Ecological and Evolutionary Responses to Recent Climate Change. Annual Review of Ecology, Evolution, and Systematics. https://doi.org/10.1146/annurev.ecolsys.37.091305.110100

Patten, M. A., \& Pruett, C. L. (2009). The Song Sparrow, Melospiza melodia, as a ring species: Patterns of geographic variation, a revision of subspecies, and implications for speciation. Systematics and Biodiversity, 7(1), 33-62. https://doi.org/10.1017/S1477200008002867

Peters, W., Hebblewhite, M., Mysterud, A., Spitz, D., Focardi, S., Urbano, F., Morellet, N., Heurich, M., Kjellander, P., Linnell, J. D. C., \& Cagnacci, F. (2017). Migration in geographic and ecological space by a large herbivore. Ecological Monographs, 87(2), 297-320. https://doi.org/10.1002/ecm.1250

Plummer, K. E., Siriwardena, G. M., Conway, G. J., Risely, K., \& Toms, M. P. (2015). Is supplementary feeding in gardens a driver of evolutionary change in a migratory bird species? Global Change Biology, 21(12), 4353-4363. https://doi.org/10.1111/gcb.13070

Postma, E., Heinrich, F., Koller, U., Sardell, R. J., Reid, J. M., Arcese, P., \& Keller, L. F. (2011). Disentangling the effect of genes, the environment and chance on sex ratio variation in a wild bird population. Proceedings of the Royal Society B: Biological Sciences, 278(1720), 2996-3002. https://doi.org/10.1098/rspb.2010.2763

Pruett, C. L., Arcese, P., Chan, Y. L., Wilson, A. G., Patten, M. A., Keller, L. F., \& Winker, K. (2008). Concordant and discordant signals between genetic data and described subspecies of pacific coast song sparrows. Condor. https://doi.org/10.1525/cond.2008.8475

Pruett, C. L., \& Winker, K. (2010). Alaska Song Sparrows (Melospiza Melodia) Demonstrate that Genetic Marker and Method of Analysis Matter in Subspecies Assessments. Ornithological Monographs. https://doi.org/10.1525/om.2010.67.1.162

Pulido, F. (2007). The Genetics and Evolution of Avian Migration. BioScience, 57(2), 165-174. 
https://doi.org/10.1641/B570211

Radchuk, V., Reed, T., Teplitsky, C., van de Pol, M., Charmantier, A., Hassall, C., Adamík, P., Adriaensen, F., Ahola, M. P., Arcese, P., Miguel Avilés, J., Balbontin, J., Berg, K. S., Borras, A., Burthe, S., Clobert, J., Dehnhard, N., de Lope, F., Dhondt, A. A., ... Kramer-Schadt, S. (2019). Adaptive responses of animals to climate change are most likely insufficient. Nature Communications, 10(1). https://doi.org/10.1038/s41467-019-10924-4

Reid, J. M., \& Arcese, P. (2020). Recent immigrants alter the quantitative genetic architecture of paternity in song sparrows. Evolution Letters. https://doi.org/10.1002/evl3.162

Reid, J. M., Arcese, P., Nietlisbach, P., Wolak, M. E., Muff, S., Dickel, L., \& Keller, L. F. (2021). Immigration counter-acts local micro-evolution of a major fitness component: Migration-selection balance in free-living song sparrows. Evolution Letters, 5(1), 48-60. https://doi.org/10.1002/ev13.214

Reid, J. M., Travis, J. M. J., Daunt, F., Burthe, S. J., Wanless, S., \& Dytham, C. (2018). Population and evolutionary dynamics in spatially structured seasonally varying environments. Biological Reviews, 93(3), 1578-1603. https://doi.org/10.1111/brv.12409

Rellstab, C., Zoller, S., Walthert, L., Lesur, I., Pluess, A. R., Graf, R., Bodénès, C., Sperisen, C., Kremer, A., \& Gugerli, F. (2016). Signatures of local adaptation in candidate genes of oaks ( Quercus spp.) with respect to present and future climatic conditions. Molecular Ecology, 25(23), 5907-5924. https://doi.org/10.1111/mec.13889

Root, T. (1988). Energy constraints on avian distributions and abundances. Ecology, 69(2), 330-339. https://doi.org/10.2307/1940431

Root, T. L., Price, J. T., Hall, K. R., Schneider, S. H., Rosenzweig, C., \& Pounds, J. A. (2003). Fingerprints of global warming on wild animals and plants. Nature. https://doi.org/10.1038/nature01333

Sæther, B. E., Grøtan, V., Engen, S., Coulson, T., Grant, P. R., Visser, M. E., Brommer, J. E., Grant, B. R., Gustafsson, L., Hatchwell, B. J., Jerstad, K., Karell, P., Pietiäinen, H., Roulin, A., Røstad, O. W., \& Weimerskirch, H. (2016). Demographic routes to variability and regulation in bird populations. Nature Communications, 7(1), 1-8. https://doi.org/10.1038/ncomms12001

Sardell, R. J., Arcese, P., Keller, L. F., \& Reid, J. M. (2012). Are there indirect fitness benefits of female extra-pair reproduction? Lifetime reproductive success of within-pair and extra-pair offspring. American Naturalist. https://doi.org/10.1086/665665

Schluter, D., \& Smith, J. N. M. (1986). Natural selection on beak and body size in the song sparrow. Evolution, 40(2), 221-231. https://doi.org/10.1111/j.1558-5646.1986.tb00465.x

Schluter, Dolph. (2000). Ecological Character Displacement in Adaptive Radiation. The American Naturalist. https://doi.org/10.1086/303412

Sexton, J. P., McIntyre, P. J., Angert, A. L., \& Rice, K. J. (2009). Evolution and ecology of species range limits. Annual Review of Ecology, Evolution, and Systematics, 40, 415-436. https://doi.org/10.1146/annurev.ecolsys.110308.120317

Shaw, A. K., \& Levin, S. A. (2011). To breed or not to breed: A model of partial migration. Oikos, 120(12), 1871-1879. https://doi.org/10.1111/j.1600-0706.2011.19443.x

Shephard, J. M., Rycken, S., Almalik, O., Struyf, K., \& Erp van der Kooij, L. (2015). Migration strategies revealed by satellite tracking among descendants of a population of European white stork (Ciconia ciconia) reintroduced to Belgium. Journal of Ornithology, 156(4), 943-953. https://doi.org/10.1007/s10336-015-1204-7

Shuford, W. D., Gardali, T., \& Editors. (2008). California Bird Species of Special Concern: A ranked assessment of species, subspecies, and distinct populations of birds of immediate conservation concern in California. Studies of Western Birds 1. In 2008.

Smith, J. N. M., Keller, L. F., Marr, A. B., \& Arcese, P. (2006). Conservation and biology of small populations: the song sparrows of Mandarte Island. Oxford University Press. 
844

845

846

847

848

849

850

851

852

853

854

855

856

857

858

859

860

861

862

863

864

865

866

867

868

869

870

871

872

873

874

875

876

877

878

879

880

881

882

883

884

885

886

887

888

889

890

891

892

Smith, J. N. M., Keller, L. F., Marr, A. B., \& Arcese, P. (Eds.). (2006). Conservation and Biology of Small Populations: The Song Sparrows of Mandarte Island. Oxford University Press, USA.

Stoks, R., Geerts, A. N., \& De Meester, L. (2014). Evolutionary and plastic responses of freshwater invertebrates to climate change: Realized patterns and future potential. Evolutionary Applications. https://doi.org/10.1111/eva.12108

Strimas-Mackey, M., Miller, E., \& Hochachka, W. (2018). auk: eBird Data Extraction and Processing with AWK. R Package Version 0.3.0.

Tarwater, C. E., \& Arcese, P. (2017). Age and years to death disparately influence reproductive allocation in a short-lived bird. Ecology. https://doi.org/10.1002/ecy.1851

Tarwater, C. E., \& Arcese, P. (2018). Individual fitness and the effects of a changing climate on the cessation and length of the breeding period using a 34-year study of a temperate songbird. Global Change Biology, 24(3), 1212-1223. https://doi.org/10.1111/gcb.13889

Teplitsky, C., \& Millien, V. (2014). Climate warming and Bergmann's rule through time: is there any evidence? Evolutionary Applications, 7(1), 156-168. https://doi.org/10.1111/eva.12129

Tompa, F. (1963). Factors Determining the Number of Song Sparrows Melospiza melodia (Wilson) on Mandarte Island, B.C., Canada [University of British Columbia]. https://doi.org/10.14288/1.0105794

Tredennick, A. T., Hooten, M. B., \& Adler, P. B. (2017). Do we need demographic data to forecast plant population dynamics? Methods in Ecology and Evolution, 8, 541-551. https://doi.org/10.1111/2041210X.12686

Visty, H., Wilson, S., Germain, R., Krippel, J., \& Arcese, P. (2018). Demography of sooty fox sparrows (Passerella unalaschcensis) following a shift from a migratory to resident life history. Canadian Journal of Zoology, 96(5), 436-440. https://doi.org/10.1139/cjz-2017-0102

Wade, M. J., \& Kalisz, S. (1990). The causes of natural selection. Evolution, 44(8), 1947-1955. https://doi.org/10.1111/j.1558-5646.1990.tb04301.x

Walsh, J., Benham, P. M., Deane-Coe, P. E., Arcese, P., Butcher, B. G., Chan, Y. L., Cheviron, Z. A., Elphick, C. S., Kovach, A. I., Olsen, B. J., Shriver, W. G., Winder, V. L., \& Lovette, I. J. (2019). Genomics of rapid ecological divergence and parallel adaptation in four tidal marsh sparrows. Evolution Letters, 3(4), 324-338. https://doi.org/10.1002/ev13.126

Wang, T., Campbell, E. M., O’Neill, G. A., \& Aitken, S. N. (2012). Projecting future distributions of ecosystem climate niches: Uncertainties and management applications. Forest Ecology and Management. https://doi.org/10.1016/j.foreco.2012.05.034

Wang, T., Hamann, A., Spittlehouse, D., \& Carroll, C. (2016). Locally downscaled and spatially customizable climate data for historical and future periods for North America. PLoS ONE, 11(6). https://doi.org/10.1371/journal.pone.0156720

Wiens, J. A., Stralberg, D., Jongsomjit, D., Howell, C. A., \& Snyder, M. A. (2009). Niches, models, and climate change: Assessing the assumptions and uncertainties. Proceedings of the National Academy of Sciences of the United States of America, 106, 19729-19736. https://doi.org/10.1073/pnas.0901639106

Williams, H. M., Siegrist, J., \& Wilson, A. M. (2021). Support for a relationship between demography and modeled habitat suitability is scale dependent for the purple martin Progne subis. Journal of Animal Ecology, 90(2), 356-366. https://doi.org/10.1111/1365-2656.13369

Wilson, S., \& Arcese, P. (2003). El Niño drives timing of breeding but not population growth in the song sparrow (Melospiza melodia). Proceedings of the National Academy of Sciences of the United States of America, 100(19), 11139-11142. https://doi.org/10.1073/pnas.1931407100

Wilson, S., Norris, D. R., Wilson, A. G., \& Arcese, P. (2007). Breeding experience and population density affect the ability of a songbird to respond to future climate variation. Proceedings of the Royal Society B: Biological Sciences. https://doi.org/10.1098/rspb.2007.0643

Wingfield, J. C. (1985). Influences of weather on reproductive function in male Song sparrows, 
902

903

904

905

906

907

908

909

910

911

912

913

914

915

916

917
Melospiza melodia. Journal of Zoology, 205(4), 525-544. https://doi.org/10.1111/j.14697998.1985.tb03542.x

Wolak, M. E., Arcese, P., Keller, L. F., Nietlisbach, P., \& Reid, J. M. (2018). Sex-specific additive genetic variances and correlations for fitness in a song sparrow (Melospiza melodia) population subject to natural immigration and inbreeding. Evolution. https://doi.org/10.1111/evo.13575

Wolak, M. E., \& Reid, J. M. (2016). Is pairing with a relative heritable? Estimating female and male genetic contributions to the degree of biparental inbreeding in song sparrows (Melospiza melodia). American Naturalist. https://doi.org/10.1086/686198

Wright, M. N., \& Ziegler, A. (2017). ranger : A Fast Implementation of Random Forests for High Dimensional Data in $C++$ and R. Journal of Statistical Software, 77(1). https://doi.org/10.18637/jss.v077.i01

Wright, S. (1982). The Shifting Balance Theory and Macroevolution. Annual Review of Genetics. https://doi.org/10.1146/annurev.ge.16.120182.000245

Yackulic, C. B., Blake, S., \& Bastille-Rousseau, G. (2017). Benefits of the destinations, not costs of the journeys, shape partial migration patterns. Journal of Animal Ecology, 86(4), 972-982. https://doi.org/10.1111/1365-2656.12679

Zuckerberg, B., Bonter, D. N., Hochachka, W. M., Koenig, W. D., DeGaetano, A. T., \& Dickinson, J. L. (2011). Climatic constraints on wintering bird distributions are modified by urbanization and weather. Journal of Animal Ecology, 80(2), 403-413. https://doi.org/10.1111/j.13652656.2010.01780.x

Zurell, D. (2017). Integrating demography, dispersal and interspecific interactions into bird distribution models. In Journal of Avian Biology. https://doi.org/10.1111/jav.01225 